MONETARY POLICY SINCE 1971

Conduct and Performance 
Also by Maximilian Hall

The Framework of United Kingdom Monetary Policy 1971-81

(with G. E. J. Dennis, D. T. Llewellyn and J. G. Nellis) 


\title{
Monetary Policy Since 1971
}

Conduct and Performance

\author{
Maximilian Hall \\ Department of Economics, Loughborough University
}

$\mathbf{M}$ 
๑) Maximilian J. B. Hall 1983

Softcover reprint of the hardcover 1st edition 1983

All rights reserved. No part of this publication may be reproduced or transmitted, in any form or by any means, without permission.

First published 1983 by

THE MACMILLAN PRESS LTD

London and Basingstoke

Companies and representatives throughout the world

ISBN 978-0-333-33142-2

ISBN 978-1-349-17111-8 (eBook)

DOI 10.1007/978-1-349-17111-8

Typeset in Great Britain by

Multiplex Techniques Limited, Orpington, Kent

The paperback edition of this book is sold subject to the condition that it shall not, by way of trade or otherwise, be lent, re-sold, hired out, or otherwise circulated without the publisher's prior consent in any form of binding or cover other than that in which it is published and without a similar condition including this condition being imposed on the subsequent purchaser. 
To my Wife and Parents 


\section{Contents}

PREFACE ix

LIST OF TABLES Xi

GLOSSARY xii

ABBREVIATIONS XV

1 THE ADVENT OF COMPETITION AND CREDIT CONTROL

Competition

Credit control

Control of the money stock 5

2 ARRANGEMENTS UNDER CCC

Competition $\quad 7$

Reserve requirements $\quad 7$

Control of the money stock $\quad 8$

Appendix: reserve 'creation' 11

3 CCC IN OPERATION: PERIOD 1

(OCTOBER 1971-DECEMBER 1973) 14

4 CCC IN OPERATION: PERIOD 2

(JANUARY 1974-APRIL 1979) 20

Background 20

Monetary instruments 23

Lending guidelines $\quad 23$

Minimum Lending Rate $\quad 24$

The special deposit scheme 24

Official transactions in the gilt-edged market 26

The 'corset' 30

Monetary targets: June 1976-June 1979

5 THE MONETARY REFORM DEBATE 55

Why monetary reform was necessary $\quad 55$

Reform proposals $\quad 58$

Monetary base control $\quad 58$

Indicator systems 66

Negotiable entitlements $\quad 67$

$\begin{array}{ll}\text { 'Other' } & 68\end{array}$ 
6 THE TORIES' FIRST YEAR IN OFFICE

(MAY 1979-MARCH 1980) 70

Targeting experience $\quad 71$

The PSBR $\quad 73$

Inflation $\quad 73$

The abolition of exchange controls $\quad 74$

Portfolio diversification $\quad 76$

Disintermediation through the Eurosterling market 81

UK banks' 'switching-out' operations $\quad 83$

UK banks' foreign currency lending to domestic residents 85

The build-up of resident-owned foreign currency deposits 86

The return of sterling to a reserve currency role 86

7 THE MEDIUM-TERM FINANCIAL STRATEGY 88

8 THE MEDIUM-TERM FINANCIAL STRATEGY IN

OPERATION

Control of the money supply 101

PSBR control 109

1980-1: 'blown off course' 109

1981-2: 'attempts to get back on course' 110

The 'costs' of the MTFS 114

9 THE 'NEW' MONETARY ARRANGEMENTS 122

Changes in the techniques of monetary control 122

REFLECTIONS 131

APPENDICES 133

A. Reserve availability 133

B. Official transactions in the money markets 137

C. Official transactions in the gilt-edged market 138

D. The 'direct' monetary effects of the balance of payments 139

Accounting identities 139

'Fixed' exchange rates 141

'Floating' exchange rates 144

E. The abolition of exchange controls 150

Implications for monetary control through

observance of $\AA_{3}$ targets 150

Implications for monetary control through the 'corset' 152

POSTSCRIPT: THE MARCH 1982 BUDGET 154

END-NOTES 156

REFERENCES $\quad 175$

$\begin{array}{ll}\text { INDEX } & 181\end{array}$ 


\section{Preface}

This book has resulted from a series of research papers written during my first three years as a lecturer in the field of monetary economics and reflects a personal bias towards the institutional framework within which monetary policy is conducted. Accordingly, the dependence of the efficacy of monetary instruments on the response of economic agents, notably the banks, to policy manoeuvres is stressed, reflecting the importance of the regulatory environment within which financial transactions are conducted. Apart from the establishment of the theoretical rationale for the adoption of individual instruments, emphasis is given to an assessment of the 'success' of policy action from the points of view of both the ability of the prevailing administration to meet its stated policy (especially financial) objectives and the overall effect on broader macroeconomic goals.

The starting-point of the text is a review of the recommendations of the National Board for Prices and Incomes (Report No. 34 on Bank Charges) and the Monopolies Commission (Barclays Bank Ltd., Lloyds Bank Ltd. and Martins Bank Ltd., A Report on the Proposed Merger) which, towards the end of the 1960 s, inquired into various aspects of monetary policy, and reported critically on the harmful effects of 'direct' controls, such as lending ceilings and interest-rate agreements, for competition between 'like' institutions and within the financial sector more generally. In apparent acceptance of many of these criticisms a new monetary control regime was instituted in 1971 under the name of competition and credit control (CCC), which represented an attempt to improve the competitive environment in the financial field and to tighten control over credit and monetary aggregate growth through a respecification of balance-sheet ratio control and a revision of the Government Broker's dealing tactics in the gilt-edged market. By December 1973, however, with the appearance of the 'corset', all faith in the willingness of the monetary authorities to adhere to the principles of CCC had vanished. The reasons for this and the need for a new form of 'direct' control are closely documented, as are the modus operandi of the 'corset' and its extensive effects on the financial system.

Chapter 5 provides a review of the monetary reform debate (including a detailed analysis of the case for monetary base control, $\mathrm{MBC}$ ) that arose as a result of dissatisfaction with the conduct of 
policy that persisted with the 'corset' scheme, and leads, in chronological fashion, to the Tories' first year in office (1979). The pervasive, free-market philosophy embraced by the new administration first appears in the abolition of exchange control, and the monetary implications of this move, both in theory and practice, are carefully elaborated. Chapters 7 and 8, respectively, cover the theoretical case for, and 'real-world' implications of, the Tories' full financial plans unveiled in the guise of the medium term financial strategy (MTFS) in March 1980. The evidence presented to and views expressed by the Treasury and Civil Service Committee inquiring into the conduct of monetary policy are analysed within this context.

The final chapters cover the 'new' monetary arrangements introduced in August 1981 and early experience with the changed control techniques. The series of appendices is designed to clarify for the more discerning reader those, mainly theoretical, topics that are given only cursory treatment in the text.

The book is intended for second- and third-year undergraduate courses in monetary/financial economics and should also appeal to students undertaking the Institute of Bankers' Examinations in Applied Economics and those generally involved or interested in the financial sector of the UK economy.

Finally, I would like to thank my colleagues at Loughborough and Nottingham Universities who provided helpful comments, suggestions and insights, especially Brian Tew, who enthusiastically undertook the daunting task of reading the whole script in draft form and provided much helpful advice and clarification. Last, but by no means least, I would like to express my sincere thanks to $\mathrm{Su}$ Spencer for all the patience shown and hard work involved in typing the entire script.

Loughborough

MAXIMILIAN HALL

November 1982 


\section{List of Tables}

4.1 Duke of York operations

4.2 Application of the corset

4.3 Corset effects in practice

4.4 Destruction of IBELs relative to $\AA^{2} M_{3}$ through the discount market

4.5 Reserve asset 'pressure' during the operation of the corset

4.6 Interest-rate effects of the corset

4.7 The relative advantages of different monetary aggregates as intermediate targets

4.8 Early UK targeting experience

6.1 Data illustrating the effects of the abolition of exchange controls

7.1 The direct monetary effects of financing the PSBR 91

7.2 The PSBR/£M $\mathbf{M}_{3}$ relationship 1973-80 95

$\begin{array}{lr}8.1 \text { Targets' experience post-May } 1979 & 101\end{array}$

8.2 The demise of the corset: expectations fulfilled 102

8.3 Indicators of economic 'performance' (April 1979-December 1981)

Appendices

A1 'Residual' supply of Treasury bills to banks and finance houses

A2 Fixed exchange rates: summary of results

A3 Floating exchange rates: summary of results 


\section{Glossary}

\section{Definitions of money}

$\mathrm{M}_{0}$ (monetary base): notes and coin in circulation with the non-bank public plus banks' balances at the Bank of England.

$\mathrm{M}_{1}$ : notes and coin in circulation with the non-bank public plus UK non-bank private-sector-owned sterling sight deposits (interest and non-interest-bearing) held with monetary sector institutions. (An adjustment is made for items in transit - see eligible liabilities.)

$\mathrm{M}_{2}: \mathrm{M}_{1}+$ clearing banks' 7-day time deposits.

$\mathrm{M}_{3}$ : notes and coin in circulation with the non-bank public, plus UKowned (non-bank private and public sector) sterling deposits held with monetary sector institutions, plus all UK-resident-owned foreign currency deposits. (An adjustment is made for items in transit - see eligible liabilities.)

$\mathrm{EM}_{3}$ : the sterling component of $\mathrm{M}_{3}$.

DCE: defined on p.50.

$\mathrm{PSL}_{1}$ : notes and coin in circulation with the non-bank public plus UK non-bank private-sector-owned sterling time (excl. deposits of an original maturity of over two years) and sight deposits (including certificates of deposit), certificates of tax deposit (gross), and Treasury bills, bank bills and local authority temporary debt (all net).

$\mathrm{PSL}_{2}$ : $\mathrm{PSL}_{1}$ (minus certificates of tax deposit (gross)) plus UK nonbank private-sector-owned certificates of tax deposit (net) and savings deposits (with building societies and the National Savings Bank) and securities (premium bonds, British Savings Bonds, National Savings stamps and gift tokens) (all net).

\section{demand-for-money function}

mathematical representation of the relationship between the demand for money (however defined) and its major determinants (e.g. income, wealth, yields). 


\section{disintermediation}

financial transactions that bypass the banks, usually as a result of the imposition of direct controls on certain banking activities which are not extended to other types of financial institution or activity.

\section{eligible liabilities}

sterling deposits of the banking system as a whole, excluding deposits having an original maturity of over two years, plus any resources obtained by switching foreign currencies into sterling, plus net interbank deposit liabilities, plus net sterling certificate of deposit liabilities, plus the banks' net sterling deposit liabilities to their overseas offices. An adjustment was made for items in transit by subtracting 60 per cent of their net debit value.

\section{eligible reserve assets}

comprising: bankers' balances (excl. special deposits) at the Bank of England; money at call with the 'Discount Market'; British government and Northern Ireland Treasury bills; British government (and government-guaranteed nationalised industries') stock of less than one year to maturity; 'eligible' local authority bills; 'eligible' commercial bills (up to a maximum of 2 per cent of eligible liabilities); and company tax reserve certificates.

\section{Eurosterling market}

sterling liabilities and claims of banks located outside the United Kingdom.

\section{gradualist approach (to curing inflation)}

a 'medium-term' cure for inflation (in recognition of the significant short-run 'costs' of a sharp deflation) involving a progressive reduction in monetary aggregate growth as a means of favourably influencing inflation expectations.

\section{'hard' arbitrage ('round-tripping')}

the practice of borrowing from banks at 'base-related' rates of interest and redepositing (e.g. through the purchase of bank certificates of deposit) at 'market-related' rates whenever profitable opportunities arise.

\section{'natural' rate of unemployment}

defined on p.169. 
xiv

Glossary

\section{Phillips curve}

graphical presentation of the time-series relationship between inflation (originally wage inflation) and the level of unemployment.

public sector borrowing requirement (PSBR)

the difference between the expenditure and receipts arising from the various activities of the public sector as a whole (central government, local authorities and public corporations).

reintermediation

the reflux of business to the banks, usually as a result of the removal of distortive, direct, controls. 


\title{
Abbreviations
}

\author{
BEQB Bank of England Quarterly Bulletin \\ BIS Bank for International Settlements \\ BL British Leyland \\ BSC British Steel Corporation \\ CB Commercial Bill \\ CCC Competition and Credit Control \\ CD Certificate of Deposit \\ CEPG Cambridge Economic Policy Group \\ CGBR Central Government Borrowing Requirement \\ DCE Domestic Credit Expansion \\ DM Discount Market \\ ECF External and Foreign Currency Finance \\ ECGD Export Credit Guarantee Department \\ ECU European Currency Unit \\ EEA Exchange Equalisation Account \\ EFL External Financing Limit \\ ELs Eligible Liabilities \\ EMS European Monetary System \\ ER Exchange Rate \\ GDFCF Gross Domestic Fixed Capital Formation \\ GDP Gross Domestic Product \\ IBELs Interest-Bearing Eligible Liabilities \\ (IB)ELs Eligible Liabilities and possibly Interest-Bearing Eligible \\ Liabilities \\ ICL International Computers Ltd \\ IMF International Monetary Fund \\ LA Local Authority \\ LDMA London Discount Market Association \\ LDT Licensed Deposit-Taking Institution \\ LIBOR London Inter-Bank Offered Rate \\ MBC Monetary Base Control \\ MC Monopolies Commission \\ MLR Minimum Lending Rate \\ MTFS Medium Term Financial Strategy \\ NBPS Non-Bank Private Sector \\ NIBELs Non-Interest-Bearing Eligible Liabilities \\ NIESR National Institute of Economic and Social Research
}


NIS National Insurance Surcharge

OPEC Organisation of Petroleum-Exporting Countries

PIB National Board for Prices and Incomes

PRT Petroleum Revenue Tax

PSD Public-Sector Debt

PSFD Public-Sector Financial Deficit

RAs Reserve Assets

RPI Retail Price Index

SDs Special Deposits

SDR Special Drawing Right

SSDs Supplementary Special Deposits

TB Treasury Bill

TCSC Treasury and Civil Service Committee

TPI Tax and Price Index

TSB Trustee Savings Bank

TUC Trades Union Congress

VAT Value Added Tax 